\title{
Ondřej Vodička, Exil českého a moravského duchovenstva za husitských válek
}

Edice středověk, Nakladatelství Lidové noviny, Praha 2019, 276 s., ISBN 978-80-7422-703-5

Jak už napovídá samotný název knihy Ondřeje Vodičky, při svém bádání se autor zaměřil na nesnadný fenomén exilu českého a moravského duchovenstva za husitských válek. Dal si tak za cíl vyplnit pomyslné prázdné místo na tomto poli, nebot' otázkám spojeným s exilem byly doposud $\mathrm{v}$ odborné literatuře věnovány především studie a kratší texty, zaměřující se na jednotlivé osobnosti, skupiny exulantů či specifické problémy. S jedinou výjimkou práce Jaroslava Kadlece tedy zatím nebylo přistoupeno k přehledové monografii, která by tuto problematiku souhrnně přiblížila. ${ }^{1}$ Jak poznamenává sám autor, svůj podíl na tom nese kromě jiných důvodů především charakter pramenné základny, pro niž je typická fragmentárnost a torzovitost. Jednotlivé zmínky o exulantech jsou tak rozesety nejen $\mathrm{v}$ široké paletě různých typů pramenů, ale také na velké ploše celé střední Evropy, což značně znesnadňuje bádání. Zájem o fenomén exilu byl navíc v určitých obdobích, a to zvláště v prŕípadě katolických autorů, zatížen ideovým nánosem.

Už z výše zmíněných důvodů je proto Vodičkova kniha, usilující o podání uceleného komplexního pohledu na exil katolického duchovenstva z Čech a Moravy, chronologicky vymezená lety 1419-1436, př́nosem pro historické bádání. Autorův zájem o dané téma má dlouhodobý charakter - publikace je přepracováním jeho disertační práce, jejímuž vydání navíc předcházelo sepsání několika odborných článkủ. ${ }^{2}$ Vodičkův široký rozhled, který je předpokladem precizního zpracování a opravdového porozumění předmětu studia, dále dokládá fakt, že pracoval ve více než třiceti českých a zahraničních archivech. Stejně tak je patrná jeho velmi dobrá znalost odborné literatury, z níž jeho kniha vychází.

Publikaci je možné rozdělit na dva základní oddíly - výklad a poté velice rozsáhlé prílohy, které jsou rovnocenným pandánem k části první. Samotný text počíná úvodem obsahujícím stručnou charakteristiku pramenné základny a odborné literatury a vymezení zkoumaného tématu doplněné o rozbor hlavního pojmu exil/exulant, s nímž kniha pracuje. Kromě kratší počáteční kapitoly a závěru je zbylá výkladová část rozdělena na tři hlavní tematické kapitoly, přičemž každá z nich nahlíží na fenomén exulantství prizmatem určitého okruhu otázek. Toto vhodně zvolené rozvržení tak poskytuje autorovi přehledný rámec pro vyprávění a čtenáři umožňuje snadnou orientaci $\mathrm{v}$ jednotlivých problémech a jejich plné pochopení. Výsledkem je poté poměrně plastický obrázek údělu exulantů doprovázený

Jaroslav Kadlec, Katoličtí exulanti čeští doby husitské, Praha 1990.

2 Ondřej VoDIČKa, Katoličtí exulanti ze zemí Koruny české v době husitské (1419-1436), disertační práce, FF MU, Brno 2016. Z článků viz např́klad TÝž, Cisterciáci z Nepomuku v exilu za husitských válek (14191436), Studia Mediaevalia Bohemica 6, 2014, s. 255-274; TÝž, Hrad Bezděz jako katolické centrum za husitských válek. Rekonstrukce bezdèzské katolické enklávy a církevnich pomèrư v souvisejicich lokalitách mezi léty 1419-1436, Bezděz 22, 2013, s. 5-35. 
částečným vhledem do fungování tehdejší katolické církve. Při popisu některých procesů či skutečností sice Vodička přistupuje k typologizaci do jisté míry zjednodušující, z textu je ovšem patrné, že si uvědomuje její limity. Nutno také podotknout, že přehledový charakter knihy zobecňující modely vyžaduje.

První ze tří hlavních kapitol nazvaná Exilové struktury, která vytváří základnu pro dva následné oddíly, se zaměřuje na popis organizačních struktur a pohybu jednotlivých církevních složek v exilu. Její podstatnou část tvoří sonda do činnosti české katolické církve z pohledu žitavské konzistoře. Kromě zběžného popisu jejího přesunu do Žitavy, prostoru, který tam obývala, a personálního složení autor věnuje pozornost především rozboru její úřední agendy, z níž rekonstruuje reálný dosah pravomocí konzistoře. Na př́kladu procesu obsazování beneficií zdůrazňuje, že žitavské ústředí bylo nuceno značně upravit správu pražské diecéze a jeho vliv se omezil prakticky pouze na severní a západní Čechy. Takovýto obraz činnosti konzistoře získává zejména ze zápisů v konfirmačních knihách a dále $\mathrm{z}$ tzv. tepelského kopiáře a žitavských akt. V rámci otázky reálného dosahu působení konzistoře Vodička zvláště vyzvedává důležitost posledního jmenovaného pramene, který je podle něj nejlepším odrazem skutečnosti.

Při úvahách o fungování církve za husitských válek nemohl autor opomenout ani dva zásadní problémy, s nimiž se musela její světská složka vyrovnávat - nedostatek kléru a financí. Přestože se těchto otázek z perspektivy exilu zběžně dotýká, v knize, jež si dala za cíl předložit souhrnný přehled o daném tématu, by se měly nacházet i odkazy na obecnější literaturu zabývající se těmito dvěma záležitostmi z širšího církevního hlediska. Ty ovšem $\mathrm{v}$ textu postrádám. Jako podstatnější nedostatek chápu absenci statistického či alespoň přibližného vyhodnocení údajů z konfirmačních knih ve formě tabulky, která by shromažd’ovala informace například o počtu žitavskou konzistoří udělených beneficií pro jednotlivé roky či oblasti nebo srovnávající množství tzv. „reálných“ a „nereálných“ konfirmací, pokud je lze z pramene rozlišit. ${ }^{3}$ Zbylou část první kapitoly tvoří dvě podkapitoly o exilu světského a řeholního kléru. Zvláště v první z nich vystupuje na povrch složitost zkoumání této látky, jejiž pramenná základna je velmi roztřǐštěná, čímž činí nalézání zmínek o jednotlivých exulantech mnohdy dílem náhody. Nedovoluje tak badatelům efektivní výzkum a formulování dostatečně jistých závěrů. Jedním ze spolehlivějších stanovisek, která Vodička v této části knihy přesto podtrhnul, je skutečnost, že drtivá většina světského kléru do exilu neodešla, ale alespoň vnějškově přijala čtyři pražské artikuly a udržela si tak svá beneficia.

Velice zajímavým a prínosným tematickým okruhem, v literatuře zabývající se církevními otázkami často přehlíženým, se ukázala druhá kapitola Exilová ekonomika, pojednávající o způsobech, jakými exulanti nakládali se svým movitým majetkem. Na modelových prríkladech osudů pokladů katedrály sv. Víta a sedleckého a pomuckého kláštera autor dokumentuje, že se církevní instituce mnohdy dlouhodobě připravovaly na příchod husitských válek a své movité majetky alespoň z části přesouvaly za hranice nebo do bezpečnějších oblastí Čech. Vodička se tak staví proti klasické představě o rozchvácení církevního movitého majetku rabujícími husitskými vojsky, která je tradována ve starší odborné literatuře. Nespokojuje se však pouze s konstatováním, že docházelo $\mathrm{k}$ transferu cenností z českých zemí. Cesty jednotlivých pokladů sleduje až do závěru husitských

3 K rozdělení na reálné a nereálné konfirmace autor přistupuje, aby mohl snáze odlišit konfirmační zápisy vážící se k beneficiím pod faktickou správou žitavské konzistoře od těch, na které její skutečná moc nedosahovala. 
válek, v četných případech dokonce po celé 15. století, čímž dokazuje svou tezi a zodpovídá otázku, jakým způsobem církev o svůj majetek skutečně přicházela. Ukazuje, že jednotlivé konventy byly nuceny $\mathrm{v}$ mnoha př́padech své bohatství z existenčních důvodů postupně zastavovat a odprodávat zahraničním církevním institucím či světským osobám, aby získávaly finance na nejnutnější každodenní potřeby. Jedna z podkapitol pak zabíhá do větších podrobností a na prríkladu několika řádových komunit i př́islušníků světského kléru tak pěkně rekonstruuje obrázek každodenního ekonomického zápolení exulantů a možností, pomocí nichž mohli získávat finance na svou obživu. V této souvislosti je také nutno vyzvednout, že autor plně využil potenciálu velmi dobře zachovaných pramenů cisterciáckého kláštera Ebrachu, které mu umožnily sledovat osudy konventu jeho dceřiného kláštera v Pomuku a na základě toho učinit kvalitní sondu do organizace exilu řeholníků a jejich exilové ekonomiky.

Další cestu, jak porozumět údělu exulantů, využila poslední kapitola Osobní dokumenty a exilová tvorba. Autorův př́nos je znatelný hlavně ve dvou oddílech věnujících se písemnostem neseným exulanty přes zemské hranice a poté tomu, jak vnímali svou současnou situaci a zaznamenávali ji ve své zahraniční tvorbě. Součástí prvního oddílu je také několikastránkový exkurz věnující se zrrídka dochovanému zvláštnímu typu dokumentů, které sloužily příslušníkům české církve jako doklad o jejich pravověrnosti. Tyto listiny pro ně měly zvláštní hodnotu, nebot' již před vypuknutím husitské revoluce se v Evropě začal šírit stereotyp automaticky spojující český jazyk či původ z Čech a Moravy s příslušností k utrakvismu. Apriorní podezřívání z kacírství a strach tak byly jedněmi z rozšířených nesnází, se kterými se musela většina exulantů nejen z řad církve vyrovnávat.

Jednou z nejcennějších částí publikace je podle mého názoru podkapitola Prožívání exi$l u$, která se snaží zprostředkovat čtenáři vlastní pohled exulantů na jejich nezáviděníhodný úděl. Netřeba vysvětlovat, proč je jejich perspektiva důležitým aspektem pro pochopení celého fenoménu exulantství. I když názory jednotlivých autorů vycházely z různých životních zkušeností, a logicky se tak v lecčems lišily, nachází Vodička několik společných motivů a topoi objevujících se v jejich tvorbě neustále. Patřila $\mathrm{k}$ nim především skepse z vývoje husitských válek, nostalgie po mírovém období a starost o hmotné zabezpečení. V názorové různorodosti zaujme zvláště osoba Ondřeje z Českého Brodu, který byl schopen až nezvykle objektivní reflexe katolické církve. Na husity ve svém díle pohlížel nejen jako na nepřátele, ale viděl v nich i zbloudilé duše zmatené církevním schismatem. Ve třetí kapitole Vodička mimo jiné také trefně upozorňuje na nebezpečí automatického ztotožňování zahraničního výskytu rukopisů české provenience s přítomností exulantů. Vzhledem k tomu, že klerici nakládali s knihami stejně jako s jinými cennostmi a ty se tak formou zástavy a následného odprodání přesouvaly do rukou cizích majitelů, neshodovalo se mnohdy místo jejich výskytu s migračními vlnami exulantů.

Jak bylo zmíněno $\mathrm{v}$ úvodu této recenze, podstatnou část knihy tvoří velice rozsáhlé přílohy, které značně zvyšují její význam pro badatele. Jejich součástí je kromě seznamu exilových rukopisů s přesným určením jejich dnešního uložení a edice listin a listů spjatých s ebrašským dvorem v Norimberku také soupis všech známých exilových konventů a exulantů z řad světského kléru a univerzitánů, doprovázený popisem jejich osudů za dob husitských válek. Ačkoli by tak přehledový charakter publikace mohl na první pohled budit dojem, že je přínosem hlavně pro čtenáře snažícího se v daném tématu teprve zorientovat, př́lohy z ní činí cenou pomůcku i pro pokročilé historiky věnující se výzkumu církevních 
dějin pozdního středověku. Medailonky jednotlivých exulantů také částečně nahrazují v textu chybějící oddíl věnovaný výhradně klerikům spojeným s pražským vysokým učením. Poskytují totiž přehled osudů více než pětadvaceti univerzitánů, kteří v celkovém počtu sto šestnácti prameny zachycených exulantů z řad světského kléru tvoří více než pětinu. Důvodem toho, že autor nevyhradil v publikaci prostor pro charakteristiku této zvláštní skupiny, byla kromě jiných př́čin pravděpodobně také nestejná míra dochovaných informací pro jednotlivé osoby jdoucí ruku $\mathrm{v}$ ruce $\mathrm{s}$ jejich různorodostí.

Hlavní tezi knihy je možné nalézt v názorově velice vyváženém závěru, ve kterém autor dochází na základě svého výzkumu k tvrzení, že je nutné přehodnotit dřivější pohled na exulanty jako na mučednickou skupinu vyháněnou ze země pod hrozbou smrti. Osudy jednotlivých kněží a řádových komunit dokládají, že realita byla mnohem složitějš́ než černobílá představa o pouhých dvou cestách, kterými se mohl katolický kněz vydat - kolaborace s husity nebo život $v$ utrpení. Je to patrné jak ze skutečnosti, že se konventy poměrně často připravovaly na příchod krizového období odesíláním pokladů do zahraničí, z absence dramatického zvýšení úmrtnosti farního kléru za husitské revoluce a v neposlední řadě z hojně se objevujícího důrazu na majetkové záležitosti, který dává tušit, že pro některé kleriky byl odchod ze země vyvolán odmítnutím utrakvistického principu chudé církve.

Na závěr musí být zmíněny ještě dva nedostatky. Publikace by si jednak zasloužila podrobnější rozbor odborné literatury. Druhým nedostatkem vyvolaným ovšem ve značné míře charakterem dochování pramenů, je fakt, že těžiště práce leží geograficky v Čechách a poukazy na moravské prostředí se $\mathrm{v}$ ní objevují dosti sporadicky. $\mathrm{V}$ př́ilohách nicméně nejsou moravští klerici ani řeholní konventy opomenuty. I přes tyto dvě vady je tak kniha Ondřeje Vodičky bezpochyby precizně zpracovanou a čtivou souhrnnou monografií, poskytující čtenáři pomocí zajímavých perspektiv široký vhled do tématu exilu českého a moravského duchovenstva. Její přečtení by tedy jistě měli zvážit jak neznalí, tak pokročilí zájemci o tuto látku.

Jan Rejzek

doi: $10.14712 / 23365730.2021 .7$

\section{Petra Zelenková, Sbírka univerzitních tezí z Národní knihovny ČR Národní knihovna České republiky, Praha 2020, 154 s., ISBN 978-80-7050-724-7}

Tzv. univerzitní teze, povětšinou velkoformátové, exkluzivní grafické listy ohlašující disputaci, slavnostní závěrečnou obhajobu, včetně jejího obsahu, která se až na výjimky konala na filozofických fakultách za účelem získání bakalářského nebo magisterského univerzitního gradu, představují svébytný a mimořádně zajímavý fenomén především barokního umění, kultury a vzdělanosti odrážející myšlení i senzitivitu tohoto období. Tyto teze, které si dávali zhotovit studenti, byly obecně spojené s jezuitským vysokým školstvím, nikoliv však výlučně, obdobnou formu ohlášek používaly i církevní školy jiných katolických řádů. I když základní funkcí tezí bylo slavnostní oznámení obhajob, sloužily zvláště jako pamětní list a umělecké dílo zároveň. Na tvorbě jejich předloh se podílely významné umělecké osobnosti své doby, z českých umělců mezi ně patřil i Karel Škréta. Grafické listy určené pro české prostředí vznikaly vedle Prahy především v tiskařských dílnách v Augsburgu. 